\title{
Comprehensive Analysis on Consumer Appeal by Hotel Services of Akmola Region
}

\author{
Gulmira Abisheva
}

PhD, Kokshe Academy

Almagul Nurgalieva

PhD, Professor; EAA, Director; Astana

Diana Ismailova

PhD, Profesoor; Academy of Imageology; Astana

\author{
Doi:10.5901/jesr.2015.v5n3p25
}

\begin{abstract}
In this article, we describe scientific and methodological principles of sustainable development in hotel services. A comprehensive analysis was conducted on consumer satisfaction on hotel services, namely in Akmola oblast, in the process of defining the main directions of sustainable development and securement of competitiveness within the region. It was revealed that operating procedures of strategic regional business structures and factors result in on sustainable development of the region. In the course of competitive analysis of the strengths of the hotels in question, a method of quantitative assessment of service was used to measure the appeal toward clients regarding services provided by the competitors of the same assignment and class. In this case, the level of competition of hotel-type services is defined by the cluster and contribution of consumption features (by the customer price of the service), service price, the level of service organization, and comfort level.
\end{abstract}

Keywords: hotel services, service level, comfort level, value in use, price

\section{Introduction}

Consumer experience is one of the most important factors of hotel-type services competitiveness. Sustainable development of hotel services can only be achieved on the basis of modern developments (Katushonok, 2011).And we cannot dispense with a comprehensive study of customer satisfaction with hotel-type services. Today hotel business of Kazakhstan is developing as a part of an integral tourism development program (Alisheva, Mazbayev,\& Ableeva, 2006).

Competitiveness of hotel and its services is entirely based on customer response; they are interdependent from one another. That is why it is reasonable to apply the method of quantitative assessment of service appeal toward clients regarding services provided by the competitors of the same assignment and class. Competitiveness of hotel and its services should be defined only by those features, attractive to the client.

\section{Research Methodology on Satisfaction of Consumers with Hotel Services}

Research methodology on satisfaction of consumers with hotel services consisted of three stages: planning, implementation, and analysis and interpretation of results. The first stage, planning, included the following steps: 1) specifying the method of data acceptance, 2) drawing up a questionnaire form for data acceptance, and 3)working out a sampling plan and defining selection criteria. The second stage of research involved immediate implementation of the plan. The third stage involved making analysis and interpretation of results by way of hotel customers' questionnaire survey (Abisheva, Zhumagulova, Turalina, Turalin, \& Kadochnikova, 2014).

\section{The Evaluation of Customer Preferences when Selecting a Hotel}

The questionnaire survey was used in order to find out what kind of hotels do customers prefer.

Oral and written questionnaire was conducted during the period from May to September of 2014. About 250 
respondents took part in the questionnaire, in which 90 people were interviewed orally and 160 in a written format. 38 enterprises were covered by the questionnaire.

The questionnaire embraced different enterprises, shops, educational institutions, and hotels in Kokshetau, Stepnogorsk, Burabay (Shchuchinsk), and Zerenda regions.

The goals of the questionnaire are as follows:

1. to reveal competitor companies;

2. to identify what appeal to customers the most in hotel business (price, customer price, service or comfort);

3. to determine what kind of service and comfort indexes is important in the customers' opinion.

In the process of questionnaire, customers ascertained the most preferential hotels; the questionnaire suggested the following questions:

1. How often do you use hotel services?

2. Which means of accommodation attracts you more when choosing hotel products?

3. With accommodation location, means, service, consumer price, and comfort level being equal, what other factors would be more important for you in hotel selection?

4. What class of hotels do you prefer? (indicate with the star-rating); What affects you in making the choice? At which hotel do you prefer the services?

5. Evaluate the level of significance in hotel services by providing a rating up to 10 (10 points - the highest significance level).

6. In your opinion, what kind of comfort indicators is important? (rank them according to their significance level). The results of questionnaire are listed $n$ the Table 1.

Table 1: Analysis of questionnaire results on the question, "at which hotel do you prefer the services?"

\begin{tabular}{|l|l|}
\hline & Comments \\
\hline \multirow{2}{*}{ Kokshetau } & $\begin{array}{l}77.1 \% \text { of respondents prefer means of accommodations at hotel "Dostyk," 13.6\% at hotel "Zhekebatyr," } \\
\text { and } 9.3 \% \text { at mini-hotels. }\end{array}$ \\
\hline \multirow{2}{*}{ Stepnogorsk } & $\begin{array}{l}69.4 \% \text { of respondents prefer means of accommodations at hotel "Stepnogorsk," 9.8 \% at mini-hotels, and } \\
20.8 \% \text { preferred rental accommodations. }\end{array}$ \\
\hline \multirow{2}{*}{ Zerenda region } & $\begin{array}{l}69.7 \% \text { of respondents prefer means of accommodations at health complex "Sunkar" and "Zeren," 6.8\% at } \\
\text { "Tulpar," and 23.5\% preferred rental accommodations. }\end{array}$ \\
\hline Burabay (Shchuchinsk) & $\begin{array}{l}\text { 80\% of respondents prefer means of LLP "Bereke-Burabay," } 53.8 \% \text { with accommodations at hotel "Alem," } \\
15 \% \text { at "Bereke," } 11.2 \% \text { at "Alem plus," } 6.3 \% \text { at mini-hotels, and 13.7\% preferred rental accommodations. }\end{array}$ \\
\hline
\end{tabular}

Source: Authors

Table 1 indicates that most of the tourists prefer staying in Kokshetaua thotel "Dostyk" (77.1\%); in Stepnogorskat hotel "Stepnogorsk" (69.4\%); in Zerenda region at health complex "Sunkar" (69.7\%); in Burabay (Shchuchinsk) region in the LLP "Bereke-Burabay" accommodations in hotels: "Alem" (53.8\%), "Bereke" (15\%), and "Alem plus" (11.2\%).

Table 2: Analysis of questionnaire results on the question,"with accommodation location, means, service, consumer price, and comfort level being equal, what other factors would be more important for you in hotel selection?"

\begin{tabular}{|c|c|c|c|c|c|}
\hline \multirow{2}{*}{ Hotels } & \multirow{2}{*}{ Rating of consumer group opinions } & \multicolumn{4}{|c|}{ Criteria of service classification } \\
\hline & & CSL & $\mathbf{P}$ & $\mathrm{SL}$ & $\mathrm{CL}$ \\
\hline 1 & 2 & 3 & 4 & 5 & 6 \\
\hline \multirow{2}{*}{ Hotel "Dostyk" } & $96.8 \%$ of the respondents & 33.4 & 17.3 & 20.8 & 25.3 \\
\hline & \multicolumn{5}{|l|}{ do not use hotel services - $3.2 \%$} \\
\hline Hotel "Zhekebatyr" & $100 \%$ of respondents & 31.6 & 8.6 & 26.7 & 33.1 \\
\hline \multirow{2}{*}{ Hotel "Stepnogorsk" } & $54.9 \%$ of respondents & 15.2 & 13.0 & 13.0 & 13.7 \\
\hline & \multicolumn{5}{|l|}{ do not use hotel services - $45.1 \%$} \\
\hline Health complex "Sunkar" & $100 \%$ of respondents & 30.5 & & 33.8 & 35.7 \\
\hline LLP "Bereke-Burabay" & $100 \%$ of respondents & 36.6 & 5.9 & 33.7 & 23.8 \\
\hline
\end{tabular}

Source: Authors 
The comprehensive analysis showed that most of the guests, first of all, pay attention to the CSL:

- reliability as the ability of the staff to provide in an exact way the service is promised;

- the basis for reliability is the competence of the maintenance staff;

- the degree of accessibility as an easy communication establishment with the maintenance staff;

- the image of hotel (trust to hotel);

- the level of customer trust.

A well-organized interior of the hotel, cleanliness of rooms, and neat appearance of the staff are external service quality criteria for which the guest infers the possibility of trusting a particular company;

- safety (are the production and consumption services not allied with danger or risk).

Comfort level (CL):

- room capacity: room size, the number of single rooms, suites, apartments, the availability of communicative conveniences in the room (equipment);

- condition of furniture, inventory, sanitary, and amenity facilities;

- availability and condition of food and beverage outlets;

- condition of building, driveways, hotel nearby territory arrangement (nearby territory beautification and illumination, drive ways, and hard-surface area for parking);

- hotel interior (pleasant interior, well-conditioned indoor hotel premises);

- outside design (outside view: front part, balcony, stanzas);

- availability of guest and service elevators;

- provision with information and equipment;

- provision with additional services.

Guest service level (SL):

- staff competence, knowledge, and ability;

- communications;

- maintenance staff politeness, education, delicacy, hospitality, tactfulness, and respect for the client;

- responsibility, benevolence, and readiness to provide services;

- attentiveness is characterized by an individual service and attention to the client;

- appearance: appealing values of the staff (uniform, manners, grading by services).

Means of accommodation - premises, having more than five room sand are used by legal organization, firms, individual entrepreneurs, and for part-time residence of tourists.

Room as an accommodation mean- one or several rooms with furniture, equipment, and inventory, necessary for part-time residence of tourists.

Subsequent to the results of questionnaire, the double room is the most used means of accommodation.

Respondents placed comfort indicators based to their significance level: room comfort level, availability of guest rooms, service elevators, hotel interior, outside view, and territory beautification.

Table 3: Analysis of questionnaire results on the question, "in your opinion, what kind of comfort indicators is important (rank them according to their significance level)"

\begin{tabular}{|c|l|c|}
\hline № & Comfort indicators & Share of affirmative respondents \\
\hline 1 & Room comfort level & $70 \%$ \\
\hline 2 & Guest rooms, service elevators availability & $63 \%$ \\
\hline 3 & Hotel interior & $59 \%$ \\
\hline 4 & Outside view & $48 \%$ \\
\hline 5 & Hotel territory beautification & $28 \%$ \\
\hline
\end{tabular}

Source: Authors

Questionnaire results of hotel customers assisted in the following:

1. Competitor companies are defined at the consumer market.

2. Rates of competitiveness are placed according to degree of preference at the consuming end.

3. Comfort levels are placed according to significance degree, allowing to define their sequence when competitive ability assessment. 


\section{Analysis of Competitive Strengths of Hotels Question}

In the course of competitive strengths analysis of the hotels in question, a method of quantitative assessment of service appeal was used for the clients regarding other services of the competitor with the same assignment and class (suggested by R.M. Petuhov—adapted for hotel services). The competitiveness level of hotel-type services is defined by the cluster and contribution of consumption features (by the customer price of the service), service price, the level of service organization, and comfort level (Abisheva,2013).

For competitive ability analysis of the given services of Akmola oblast, there occurs the necessity for conducting market research on classifications-small, middle-sized, and major.

Small hotel in Kokshetau is "Zhekebatyr" (***star-rating);middle-sized are "Dostyk" (*** star-rating) and Burabay village hotel "Alem." There is no major hotel in the territory of Akmola oblast.

Their choice is due to the fact that they are characterized by different groups, location, organizational structures and class of hotels, and the choice of the service predetermined that the standard double room is more popular.

Hotel "Zhekebatyr" has a number of advantages in the following parameters: the state of the material and technical base, range of additional services, timely housekeeping services, and others. The competitive advantage of the hotel "Dostyk" is the presence of free standing buildings and high prices. The disadvantages include: partial renewal of the material and technical base, lack of programs to promote services to the market, and the lack of range in additional services. The study recommended the proposal to reduce prices for services, as well as to work out the strategy in hotel business development in order to improve the competitiveness of the hotel services.

Competitive advantages of the hotel "Alem" is the presence of a detached building, high material and technical base, established program of services promotion to the market, and adequate range of additional services. Disadvantages include seasonality and high prices. The recommendations are provided or the improvement of their activities in order to improve the quality of services.

Ranking of respondents according to age allowed us to determine that the majority of visitors are in the age ranges of 20 to 50 years old at $81 \%$, younger than 20 years old at $14 \%$, and older than 50 at $5 \%$.

$58 \%$ of the respondents have a higher education; $32 \%$ have specialized secondary education, $9 \%$ are average, and $1 \%$ have in complete higher education. Furthermore, $48 \%$ areemployees;25\% are top management representatives; $12 \%$ areworkers; $14 \%$ are students; and, $1 \%$ are retired.

Consequently, the target market is people with higher education, employees, and managers. So for this category of people, additional services should be prioritized and service policy should be formed.

Based on market research, the level of maintenance staff service is revealed: at the registration, hotel reservations, transfers, food, cleanliness, and housekeeping. Respondents evaluated these parameters on a 10-point scale.

These survey of respondents showed that the level of service in hotels was different: $45.4 \%$ received full satisfaction; $30 \%$ were partially satisfied; $15.7 \%$ of respondents received a minimum satisfaction; and, $7.6 \%$ were dissatisfied with the level of service.

When evaluating the timeliness and quality of house keeping, the following results were obtained: $37 \%$ of respondents were fully satisfied;30.3\% were partially satisfied;31.7\% were not satisfied enough; and, $1 \%$ of the respondents were dissatisfied with the quality of services given.

Respondents rated the level of administrator courtesy in providing additional services as follows: $22.6 \%$ of respondents were completely satisfied with the availability of additional services; $41.6 \%$ were partially satisfied; and, $35.6 \%$ were minimally satisfied. In order to improve the functioning of the hotel enterprises, the questionnaire included the question, "identify one of the most important factors of consumer perception of hotel services. "Ranking of responses revealed that $24 \%$ of respondents chose as a significant factor such item as security, $19 \%$ as reliability, $13 \%$ as the availability, $11 \%$ as competence of the personnel, $10 \%$ as comfort, $4 \%$ as the politeness and friendliness of the staff, and $1 \%$ as the access to the Internet and the availability of additional services.

Analysis of results showed that hotel companies need to pay due attention to characteristics such as the level of consumptive qualities, level of service, level of price, and comfort.

Survey results demonstrated that hotel "Zhekebatyr" and hotel "Alem" provide high quality services. Hotel "Dostyk" provided services that did not meet the desired level. It is necessary to raise the quality of services in all aspects, especially housekeeping, maintenance, and illumination.

Thus, the main problems are the following: worn and outdated material and technical base, low salary of worker, hence, the lack of qualified personnel. Strategic directions of their development must be the improvement of the existing 
management system, funding for major repairs and reconstruction of buildings for improving services quality, an active promotion of services to the market, and the possibility of transition to a system of private management.

\section{Conclusion}

Positive trends in the development of the tourism industry, which had emerged in the country in the recent years, suggest that domestic tourism can contribute to the implementation of the Strategy of Kazakhstan's ranking among one of the fifty most competitive countries in the world. And, now "we are facing the task of creating a competitive tourism industry to ensure stable growth of state revenues and employment in the service sector of the tourism industry by increasing the volume of inbound and domestic tourism."

The active participation of Kazakhstan in all international events in the field of tourism, development of tourism clusters, public funding, attraction of private investments, and introduction of a unified system of licensing of companies are designed to promote the intensive development of the tourism industry, which is considered to be the main component of the hospitality sector.

\section{References}

Abisheva, G., Zhumagulova, A., Turalina, Z., Turalin, A., \& Kadochnikova, V. (2014). The Model of Region Stable Development Provision. American Journal of Industrial and Business Management, 4, 627-631.doi: 10.4236/ajibm.2014.411068

Abisheva, G.O. (2013). competitiveness in the hotel industry [According to issue of Akmola region]. Auto abstract. Bulgaria.

Alisheva, R.T., Mazbayev, O.B.,\&Ableeva, A.G. (2006). Hotel industry: study guide.Almaty, 119.

Katushonok, K.A. (2011). [Study level of sustainable development]. Volume of Moscow University MIA Russia, 7, 39-40. 
